\title{
Digital Education and Smart Country South Korea
}

\author{
Prof. (Dr.) Subhash Desai \\ Department of Computer Engineering, SAL Institute of Technology \& Engineering Research \\ Ahmedabad, Gujarat, INDIA
}

\begin{abstract}
There is a great evolution of education system in South Korea which is fastest, smart and digital. Once upon a time Korea was suffering from poverty and unemployment but never felt helpless. Instead of growing their industry and business in random manner, they have concentrated on strong education system to fight against conical problems of poverty and unemployment. South Korea has decided to do development on its own without taking help from World Bank. There was $22 \%$ literacy rate when it became independent. Now it has reached to $99 \%$ due to continuous hard efforts put in for number of years. We must learn and follow awesome education system to build our country and cities smart.
\end{abstract}

KEYWORDS: College level education, Education system, School level education, Smart country

\section{INTRODUCTION}

Every human needs good income and better life style. South Korea made it sweet and easy by deploying best education system. South Korea was badly looking for economical support in the beginning but most important thing was to be independent. Looking towards long term planning and growth of people, it has given priority to education compare to establishing industry for employment.

South Korea has increase per person income from $90 \$$ to $35485 \$$ now. They have proved that using new education system how domestic production is made high speed and faster development of the country. South Korea stands $15^{\text {th }}$ rank in world's largest economical condition. [1]

Education system of south Korea is consider as simple, positive, successful and admiring among all complex education system worldwide as per analysis done by educationalist. It is one of the best models of world class supreme educational skill development system. This is the reason for giving more importance to skill development programs in INDIA by our Prime Minister Shri Narendrabhai Modi. The government is able to increase college students. Even US President Barac Obama has accepted and appreciated this education system and advised world to follow it.

\section{Education System of South Korea}

The credit of success of education system goes to positive attitude of its government. Government is spending $27 \%$ amount of its budget only towards education work. Government has total control on private and government schools and colleges. Approval of new school or college is restricted by government. To pass approval process, not only students but institutes have to follow strict rules and regulations. While total control is with government, they do provide all requirements.

Chanakya has said "Teacher is not a common person but he gives birth to construction and disaster". In line of this thought, to increase the scope of education, South Korea has concentrated to develop best teachers for the country. In 1985 "The committee for educational reform" body formulated to create infrastructure development system and to remove weakness of teachers. Education policy was also undergone reform.

Instead of following hi-fi and super smart country, south Korea has taken stock what they have and how to do best use of it and implement it. They invited experts from world and taken views and suggestions to improve their educational related work. They first made list and later implemented it. [1]

\section{Methodology and Course Content}

Following points were considered in designing courses and teaching learning process.

$>$ What is the syllabus (subject content) for each course? 
$>$ How to distribute subjects in corresponding standard/class?

> Education pattern to be 6-3-3-4 meaning 6 years Primary, 3 years Secondary, 3 years higher secondary and 4 years for graduation.

$>$ How to teach and components of courses (Theory and Laboratory)?

$>$ What is important work of a Teacher?

$>$ Which subject(s) given priority and more weight age?

> How school buildings are to be constructed?

$>$ What are the facilities required to get result oriented and useful education?

First 9 years education (Primary and Secondary) is free and compulsory to all children in country. To increase the attendance of students, positive and motivation steps taken by schools. Each school is given freedom to select courses based on local need.

They have promoted the activities of students based on their interest and likings and doing monitoring of it. They also have ensured not to overload students in studies and kept emphasis on creative thinking rather than only remembering concepts. More time allocated to experiments instead of theoretical concepts. [3]

\section{Digital Education}

They have prepared Report Card for each student by integrating Reading, Mathematics and Science academy with the use of world popular PISA (Program for International Student Assessment) and always remain in top 10. Korea has exploited all benefits of Internet and expanded use of latest technology. They have used Wireless Sensor Network widely in making smart city "SANGDO".

Korea is the first country in world to create digital text material for primary and secondary education. All schools in the country are connected with high speed optical fiber broad band in order to reduce expenses and updating courseware in fastest manner. Level of education increased and economy became strong. We in INDIA invite MNCs to give us employment but South Korea government invites foreign students so that available vacant positions are filled in their local industries.
Many people criticize on Korean education system and stated that their education is directly related to its results and do not encourage extra curriculum activities outside class room. However, we must agree to that small country like South Korea (smaller than Gujarat state) have more Olympic winners than from India. [1]

\section{Smart city Songdo}

South Korea's purpose-built 'smart city', Songdo International Business District, is the largest private real estate development in history. The price tag currently stands at over $\$ 40 \mathrm{bn}$. The Songdo International Business District, constructed on a new embankment on the Incheon waterfront, is a purpose-built 'smart city', designed for efficiency and convenience.

Building a city from scratch to fulfill a specific need is not a new concept; Canberra, Brasilia and Abuja were all built in the last 60 years as functional capital cities. But Songdo is unique, being built as an integrated hi-tech environment. Developers describe Songdo as a 'global business hub' and 'home to a variety of residential and retail developments'.

The smart city occupies 1,500 acres of land making it the largest private real estate development in history. But it's not the geographical space that makes Songdo remarkable. The district was built as part of former President Lee Myung-bak's drive to promote low-carbon and sustainable growth as the principal avenue for development in South Korea.

Songdo has been a huge part of the move towards sustainable growth. The city is a novel model -40 percent of its area is dedicated to outdoor spaces. By comparison, Seoul and other South Korean metropolises are densely populated with few openair areas for residents. Songdo is unique, offering city inhabitants something they have never had access to before: green space for leisure. The district has been heavily promoting its 16 miles of bicycle lanes, its central park, and its waterways, which are based on New York City's Central Park and Venice's canals, respectively. 
Entire development adheres to the strictest environmental standards for energy consumption and waste including the Northeast Asia Trade Tower, which will be Korea's "tallest building and most advanced corporate centre," according to Songdo's promotional material.

Because the district was built from scratch, it has given developers the opportunity to invest heavily in technologies that have yet to debut in conventional cities. Take Songdo's smart rubbish disposal system, a futuristic bit of hardware that spans the whole complex. No rubbish trucks will ever roam the leafy streets of Songdo, instead all household and office waste is sucked through a network of underground tubes to vast sorting facilities where it is all processed, deodorized and treated. The aim is to eventually convert all this sorted and treated waste into energy for the community, but the system is not yet fully operational.

The city can interact with residents on a one-to-one basis. Smart grids and meters are already fairly common in Europe and the US, but the technology in Songdo is more pervasive than anything in the West. Because it was designed to this specification and not converted later like most 'smart cities' in the rest of the world, Songdo is completely geared towards sustainability; suitable for human consumption, being used in showers and toilets, and all of the embankment's water goes through a sophisticated recycling system.

Everything in Songdo might have been meticulously designed, but there is one key element that has not gone according to plan. Since its official launch in 2009, the sustainable district remains woefully under-occupied.

In order to speed up the population process, developers have been investing heavily in topquality international education centers. The hope is to entice a diverse international community. Four universities will inaugurate campuses in the business district, including the first overseas university to open a campus branch in Korea, the State University of New York, Stony Brook, as well as George Mason University and the University of Utah, all sponsored at least in part by the Ministry of Knowledge Economy. There is also an enormous, exclusive international school catering to children from kindergarten to high school.

Songdo is more than a hi-tech business district, but a template for future developments. It is the prototype for the green investment the government wants to build the economy on in the future. It is all designed to appeal to foreign investors, but its manicured gardens and glassy towers also give it an unmistakable air of luxury. This is the aspiration South Korea where everyone is wealthy and your mobile phone controls the temperature in your apartment. [2]

\section{Conclusions}

We as Indian must act fast to make our 100 cities smart. Starting from Gift City Gandhinagar, Lavasa and Dholera many more things to be achieve soon. In many ways Songdo is a living organism. The city's infrastructure contains sensors that monitor and regulate everything from temperature to energy consumption and traffic.

Songdo is the city of the future all that is missing are the residents. We have residents but "NO" smart cities. "It's the occupants who make a city" Jonathan Thorpe, CIO of Gale International, the American developer behind Songdo, told the BBC. We must do reforms to our Education System similar to digital education of South Korea.

\section{References and Other Sources}

[1] Article appeared in Gujarat Samachar dated 2206-2015.

[2] www.songdo.com

[3] www.korea.net 